\title{
Before it disappeared: ethnobotanical study of fleagrass (Adenosma buchneroides), a traditional aromatic plant used by the Akha people
}

\author{
Yi Gou ${ }^{1,2}$, Ruyan Fan ${ }^{1,2}$, Shengji Pei ${ }^{1}$ and Yuhua Wang ${ }^{1 *}$
}

\begin{abstract}
Background: Fleagrass, Adenosma buchneroides, is an aromatic perennial herb that occupies an important position in the life of the Akha people. They regard it as a tribal symbol and a gift of love. Fleagrass also has many medicinal uses, and there is considerable potential for its development as an insect repellent. Traditionally, Akha people plant it in swidden fields, but there are few swidden fields in China now. Therefore, the first question this study aims to answer is as follows: how is fleagrass planted and utilized now? At present, fleagrass is only reported to be used by Akha people in Mengla. We also try to understand the following questions: Is fleagrass used in nearby area? If so, how is fleagrass used in nearby area? Furthermore, why is fleagrass used in that way?

Methods: From August 2016 to July 2018, field surveys were conducted six times. The ethnobotanical and ethnopharmacological uses of $A$. buchneroides in 13 Akha villages were investigated by means of semi-structured interviews. We assessed the responses of a total of 64 interviewees (32 men and 32 women; mean age, 58.6) from the Xishuangbanna Dai Autonomous Prefecture, southwest China, and from Phongsaly Province, Laos. To explain the bases for the ethnobotanical uses of fleagrass, we used Google Scholar, Web of Science, and China National Knowledge Infrastructure to review the bioactivities of the chemical constituents of $A$. buchneroides.

Results: With the vanishing of swidden agriculture and the development of modern products, fleagrass cultivation is disappearing in China. However, most Akha people in Xishuangbanna still remember and yearn for its traditional uses, and Akha people in a nearby area (northern Laos) continue to plant and utilize it. We documented ten uses of A. buchneroides within five discrete categories. The whole plant of fleagrass has a distinct strong aroma, of which Akha villagers are particularly fond. Akha villagers mostly use this aromatic property as a decoration, perfume, and insect repellent. A. buchneroides is also used as a condiment and for medicinal and ritual purposes, including its use as a cure for insect bites, headaches, influenza, and diarrhoea, and as a part of pray ritual for a bumper harvest. From our literature review, we identified many major chemical compounds contained in the essential oil of $A$. buchneroides, including thymol, carvacrol, 3-carene, and p-cymene, which have insecticidal or insect-repellent, antimicrobial, and antiinflammatory properties.
\end{abstract}

Conclusion: Fleagrass is an aromatic plant that is widely used by Aka people. Its chemical composition also has a variety of biological activities. With the vanishing of swidden agriculture and the development of modern products, fleagrass utilization in China is disappearing and its cultural importance is reduced. However, its economic and medicinal value is assignable.

\footnotetext{
* Correspondence: wangyuhua@mail.kib.ac.cn

${ }^{1}$ Department of Economic Plants and Biotechnology, Yunnan Key Laboratory for Wild Plant Resources, Kunming Institute of Botany, Chinese Academy of Sciences, 132\# Lanhei Road, Kunming 650201, China

Full list of author information is available at the end of the article
}

(c) The Author(s). 2018 Open Access This article is distributed under the terms of the Creative Commons Attribution 4.0 International License (http://creativecommons.org/licenses/by/4.0/), which permits unrestricted use, distribution, and reproduction in any medium, provided you give appropriate credit to the original author(s) and the source, provide a link to the Creative Commons license, and indicate if changes were made. The Creative Commons Public Domain Dedication waiver (http://creativecommons.org/publicdomain/zero/1.0/) applies to the data made available in this article, unless otherwise stated. 


\section{Introduction}

Vector-borne diseases pose a significant threat to human life and welfare and account for approximately $17 \%$ of the global burden of infectious diseases, causing more than one million deaths each year [1]. More than $80 \%$ of the world's population live in areas with at least one major vector-borne disease risk, with more than half of the population facing two or more such risks [1]. For most vector-borne diseases, prevention by targeting vectors is the first and best approach. Use of long clothing and topical repellents for personal protection is one of proven effective vector control approaches. When considering the adverse environmental effects and the development of resistance to synthetic repellents, there is currently a greater requirement for plant-based repellents [2].

People have been combatting insects for thousands, even millions, of years. Several species of primates have been observed rubbing plants to repel insects [3]. The earliest recorded human use of plants as a repellent can be traced back to BC. Herodotus recorded that Egyptian fishermen burn castor oil in oil lamps to repel mosquitoes [4]. In the Chinese ancient book 'Zhou Li' (one of four extant collections of ritual matters of the Zhou Dynasty, 1046 B.C. to 256 B.C.), there is a record of burning plants to fumigate insects [5]. In the Arribes del Duero (western Spain), local residents reported 27 traditional uses of 22 plants to prevent or control mosquitoes, flies, and other insects. Of the 27 reported remedies, inhabitants of the area continue to use 16 (59\%), mainly against mosquitoes and houseflies [6]. Boer et al. conducted structured interviews in 66 villages of 17 ethnic groups, throughout the Lao People's Democratic Republic. A total of 92 plant species was recorded to repel or kill hematophagous arthropods, including mosquitoes, bedbugs, human lice, mites and ticks, fly larvae, and blood-sucking leeches [7]. In Africa, some places are the hardest hit areas by insect-borne diseases, where local residents still apply plants in traditional ways as an effective and economical means of insect control $[8,9]$.

Peasants of all regions knew well how to use specific local plants to protect themselves against insects. They named some of them according to the insect for which they were used to repel. For instance, almost all species in the genus Polygonum have the same local name, kirburohi, or 'flea herb' in Estonian scientific nomenclature, which is because these species are used exclusively against human fleas. The whole plant was cut, dried, and then placed on the floor or in the bed to kill fleas [10]. In addition, some special plants are endowed with special cultural meanings. A typical example is Artemisia vulgaris, which is hung on the door as part of a ceremony to drive away pests and diseases for the Dragon Boat Festival. In rural China, the burning of bundles of dried $A$. vulgaris to produce smoke had been used to repel insects for centuries [11]. After the
Dragon Boat Festival, the weather starts to heat up, and the snake worms and ants began to move. Therefore, people usually put a branch of $A$. vulgaris at their doorsteps to ward off diseases, prevent mosquitoes, and ward off evil spirits. Although modern products have replaced traditional protection, this ritual continues today.

In Mengla County of China, there is also a plant named 'fleagrass', Adenosma buchneroides. Similar to the Polygonum in Estonia, fleagrass is an insect-repellent plant that is used by the Akha people. However, fleagrass plays a broader and more important role in the culture of Akha. Akha people wear it on the head every day, because they like the smell and regard it as the symbol of Akha [12]. The smell is also good for relaxing and comforting the body. In traditional Akha medicine, the whole plant has medicinal value in anti-rheumatic, diminishing swelling, dissipate stasis, and analgesia [13]. The essential oil of fleagrass exhibited a good reduction of the population of adult insects [14]. Chemical constituents of the essential oil of fleagrass have been identified, with 39 chemical compounds reported. The main constituents include thymol, carvacrol, 3-carene, $p$-cymene, and $\beta$-phellandrene $[12,15]$. These chemicals show antimicrobial, antioxidant, phytotoxic, and insecticidal activities [16-19].

Botanically, fleagrass is an aromatic perennial herb with an erect stem and many branches that can grow to a height of $40-45 \mathrm{~cm}$. The stems are angulate, bearing paired leaves, each of which is $1.2 \times 2 \mathrm{~cm}$ in size and ovate-oblong in shape. The purple flowers form terminal spikes that bloom from October to November. The fruit is an oblong capsule that dehisces into four straw-coloured lobes when mature. The fruiting spike can be as long as $5 \mathrm{~cm}$. The numerous minute ovate seeds mature in December (Fig. 1).

Interestingly, although fleagrass is naturally distributed in Vietnam [20], there is no wild fleagrass in China. There are five other Adenosma species that are naturally distributed in China (Fig. 2), and four species are recorded as Chinese herbal medicines (A. caeruleum, A. glutinosum, A. retusilobum, and $A$. indianum) $[13,21]$.

Akha people in Mengla planted fleagrass together with rice in swidden field [12], but there are few swidden fields in China now. Therefore, the first question this study aims to answer is as follows: How is fleagrass planted and utilized now? At present, fleagrass is only reported to be used by Akha people in Mengla. We also try to understand these questions: Is fleagrass used in nearby areas? How is it used in nearby area? Furthermore, why is it used in that way?

\section{Materials and methods}

\section{Study area}

The study was carried out in 13 villages of two neighbouring areas, Xishuangbanna Prefecture (China) and Phongsaly Province (Laos), which have similarities in 


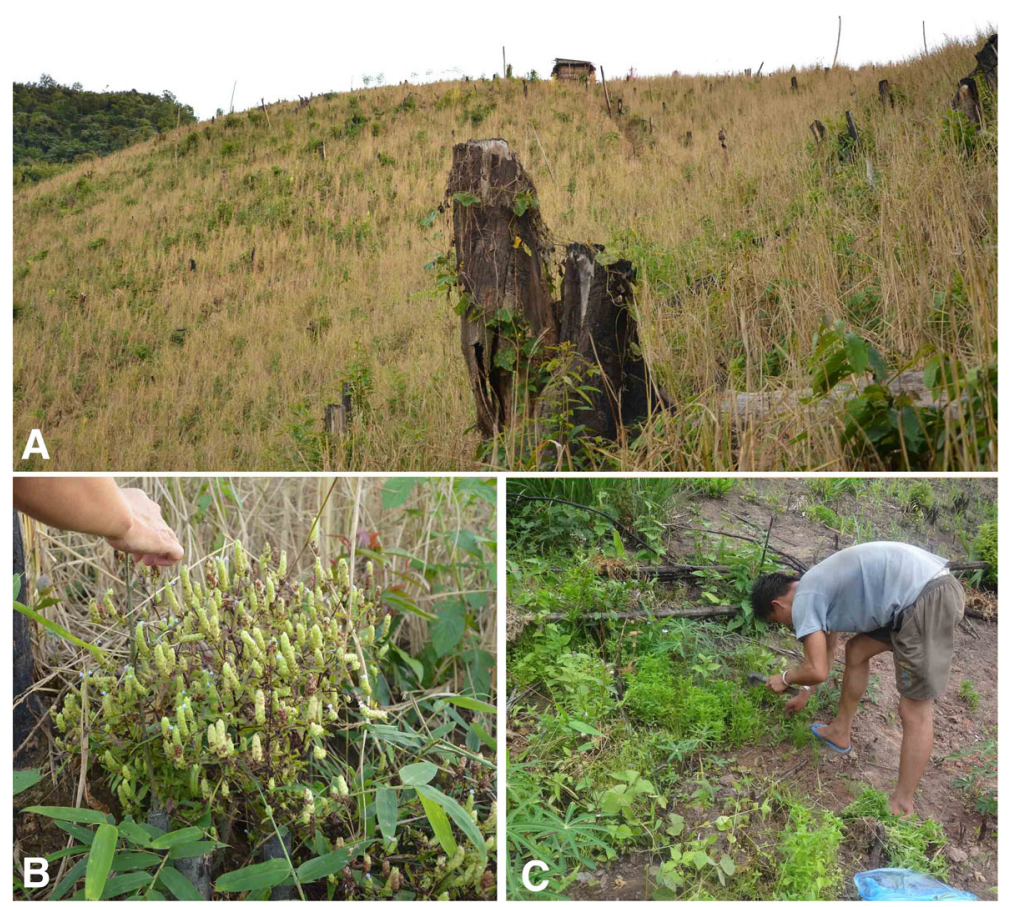

Fig. 1 Fleagrass habitat and harvest. a The habitat of fleagrass. b The harvest of ripe fleagrass. $\mathbf{c}$ The harvest of green fleagrass (photographed by YG and YW, made by A. B. Cunningham)

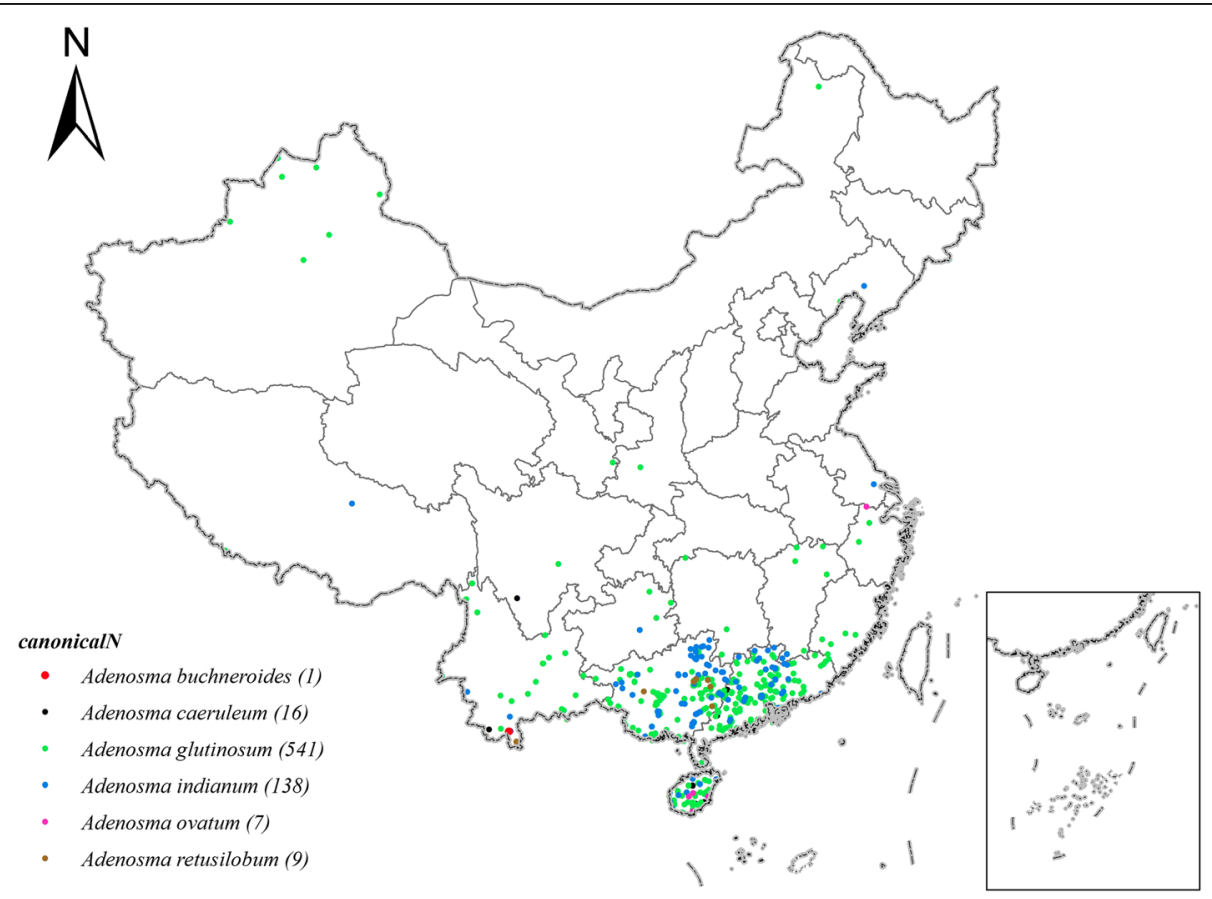

Fig. 2 Distribution of Adenosma species in China (data from GBIF, CVH, NSII) 
climate, vegetation, and culture. These areas are situated in the tropical monsoon forest zone of southeastern Asia within latitudes $20-24^{\circ} \mathrm{N}$ and longitudes $98-104^{\circ} \mathrm{E}$ (Fig. 3).

Xishuangbanna Dai Autonomous Prefecture is located in the southern-most part of Yunnan Province, southwestern China, bordering Laos and Myanmar, covering a total area of $19,125 \mathrm{~km}^{2}$ and having a population of approximately 1.18 million [22]. The Mekong River runs through the region from northwest to southeast. The climate is subtropical with a rainy season between May and October and a dry season lasting from November to
April. Annual precipitation varies from 1200 to $1900 \mathrm{~mm}$ in the valleys and uplands, of which $84 \%$ occurs during the rainy season and $16 \%$ in the dry season [23]. The Hani people are the second largest ethnic group in Xishuangbanna Prefecture, comprising approximately 19\% of the population and the majority of Hani people here are Akha, who live in the mountain and mid-mountain areas [24].

Phongsaly Province is one of the remotest Lao PDR provinces. It is dominated by a rugged, mountainous terrain and supports an abundance of thick forests and fast-flowing rivers. Most of the land lies between elevations

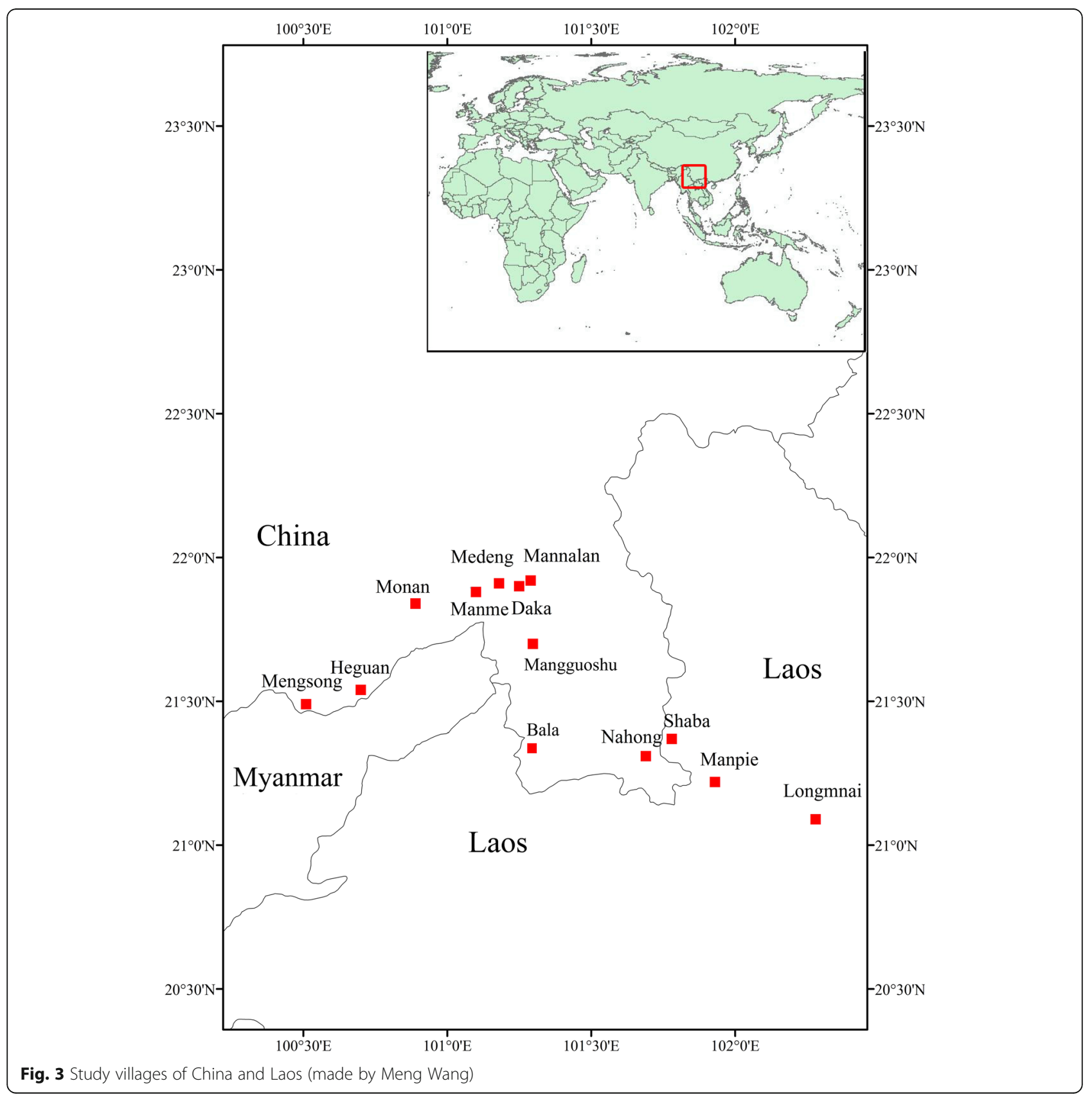


of 500 and $1500 \mathrm{~m}$, which moderates the heat of the surrounding areas and makes the climate suitable for trekking and other physical activities. Agriculture is the mainstay of the people of the province. The March 2015 census put the population of the province at 177,989. There are 13 minority ethnic groups, including the Khammu, Thai Dam, Thai Daeng, Yao, Leu, Hor, Hmong, Akha, Yang, Bid, and Lolo. Phongsaly is located between Yunnan (China) and Điện Biên Province in Vietnam. There is considerable communication among the groups here, particularly within the same ethnic tribe [25].

\section{Ethnobotanical surveys}

Field surveys were conducted in August, September, and November 2016, January and May 2017, and July 2018. Ethnobotanical data were collected through semistructured interviews with informants in Xishuangbanna Dai Autonomous Prefecture and Phongsaly Province.

With the ongoing disappearance of swidden agriculture, the resource of fleagrass in China is decreasing, and knowledge about fleagrass is currently restricted to only few people. Among these, the majority are traditional healers and herbalists, and therefore, for our survey work, we selected eight villages that are inhabited by traditional healers and herbalists. In each village, we held the first meeting with the village chief and his advisors to inform them of the purpose of our work. The village head would consent to the research and recommend traditional healers or herbalists to be interviewed for the study. Furthermore, we also interviewed some other informants who were elderly villagers or had a sound knowledge of fleagrass. With the assistance of a guide who can speak Lao, Akha, and Chinese, we also selected three Akha villages in Phongsaly Province, Laos, where they still cultivate fleagrass. In the villages of Laos, we selected informants randomly. A voucher specimen (KUN: 1341141), which was deposited in the herbarium of the Kunming Institute of Botany, China (KUN), was used as a representative sample of the plant for identification by respondents. Informants were asked whether they were able to identify the fresh plant. If they recognized the fleagrass, they were asked to provide information about their knowledge of the plant, the local name, medicinal use, place and mode of collection, preservation, plant preparation, and administration.

In total, we interviewed 64 people from 13 localities: eight in Xishuangbanna and three in Phongsaly. We obtained responses from a total of 64 interviewees from Xishuangbanna Dai Autonomous Prefecture, southwest China, and Phongsaly Province, Laos. The 64 respondents fell into three age groups: (1) 20-39, (2) 40-59, and (3) $\geq 60$ years old, with an average age of 58.6 years. Most respondents $(53 \%)$ were aged above 60 years, $36 \%$ were between 40 and 59 years old, and $11 \%$ were between 20 and 39 years old. There were 32 (50\%) female respondents and $32(50 \%)$ males. The occupation of the respondents included doctor, herbalist, witch, and village head (Additional file 1).

\section{Data analysis}

Frequency of citation (FC) is the number of informants who refer to each usage; frequency of current use (FCU) is the number of informants who continue to use them today.

\section{Literature review}

To explain the ethnobotanical knowledge of fleagrass, we surveyed the literature relating to fleagrass chemical composition and selected the constituents that are related to the uses of fleagrass. For this purpose, literature searches were conducted using Google Scholar, Web of Science, and CNKI (China National Knowledge Infrastructure). We wanted to identify scientific publications and patents describing in vitro or in vivo studies of fleagrass and the bioactive components relevant to its uses and applications. The search for biological activity was conducted individually for the species and each chemical constituent. We combined the following keywords using the Boolean operators 'AND' and 'OR': 'Adenosma buchneroides'; 'chemical compound' (e.g. thymol); 'biological'; 'pharmacological'; 'activity'; 'bioactivity'.

\section{Results and discussion}

\section{Ethnobotanical usages of fleagrass}

Fleagrass is known by Akha people with the vernacular name 'Lao-wo-suo-du', 'Lang-suo-du', and 'La-sang-suo-du'. From respondents who have an ethnobotanical knowledge of fleagrass, we recorded ten uses within five categories (Table 1). These uses from the Akha people in Xishuangbanna and Phongsaly have similarities and differences.

The whole plant has a fresh fragrance that is emitted when the living leaves are rubbed, and dried specimens retain their strong fragrance. Akha villagers are particularly fond of its scent. Both China and Laos Akha villagers put fleagrass in ear-holes or on caps as decorations or perfume (Fig. 4c). Some respondents also claimed that placing fleagrass in their ear-holes or on caps can relieve headaches. The scent is also helpful in relieving nasal congestion.

Akha villagers live in tropical and subtropical rainforests, where many types of insects are both a source of annoyance and can pose a risk to human health. As a preventative measure, in China, the Akha villagers place bundles of fleagrass in their rooms or spread fleagrass on beds to keep fleas or other insects away from human bodies (Fig. 4a). They also plant fleagrass around sheds in fields to repel insects. Fleagrass is also an important medicinal plant that is utilized by Akha people of China. They use fleagrass by making a potion for drinking to 
Table 1 Different uses of fleagrass recorded among the Akha people in Xishuangbanna and Phongsaly

\begin{tabular}{|c|c|c|c|c|c|c|c|}
\hline Parts used & Use category & Mode of preparation & Form of use & Purpose of use & Usage in China(C)/Laos(L) & FC & FCU \\
\hline \multirow[t]{5}{*}{ Aerial part } & Personal & Placed in small bundles & Worn in ear-holes or on caps & Perfume; decoration & $\mathrm{C}, \mathrm{L}$ & 34 & 9 \\
\hline & \multirow[t]{2}{*}{ Medicine } & \multirow[t]{2}{*}{ Placed in small bundles } & \multirow[t]{2}{*}{ Worn in ear-holes or on caps } & Headache & C & 11 & \\
\hline & & & & Stuffy nose & C & 2 & \\
\hline & Insecticide & Placed in small bundles & $\begin{array}{l}\text { Hung on the window/placed } \\
\text { on the floor or bed }\end{array}$ & Insect repellent & C & 22 & \\
\hline & Ritual & Placed in small bundles & Hung on the wall of granaries & $\begin{array}{l}\text { When praying for a } \\
\text { bumper harvest }\end{array}$ & $L$ & 17 & 17 \\
\hline \multirow[t]{5}{*}{ Whole plant } & \multirow[t]{2}{*}{ Medicine } & \multirow[t]{2}{*}{ Boiled in water as an infusion } & \multirow[t]{2}{*}{ Drunk as an extract } & Influenza & C & 4 & \\
\hline & & & & Diarrhoea & C & 3 & \\
\hline & \multirow[t]{3}{*}{ Insecticide } & \multirow[t]{2}{*}{ Boiled in water as an infusion } & \multirow[t]{3}{*}{ Body wash } & Insect bites & C & 7 & 3 \\
\hline & & & & Insect repellent & C & 5 & 3 \\
\hline & & Planted around the house & & Insect repellent & C & 9 & \\
\hline \multirow[t]{3}{*}{ Leaves } & \multirow[t]{2}{*}{ Medicine } & \multirow[t]{2}{*}{ Crushed leaves } & \multirow[t]{2}{*}{ Rubbed on a wound } & Insect bites & C & 17 & 5 \\
\hline & & & & Acne & C & 1 & \\
\hline & Condiment & & As a fragrance & Taste & $\mathrm{L}$ & 12 & 12 \\
\hline
\end{tabular}

gain relief from headaches, influenza, or diarrhoea, which serves as a means of family health care in remote areas. They also crush fresh fleagrass and apply it to the skin to treat insect bites, as the sap aids in relieving itching and swelling. Furthermore, they make an infusion of fleagrass by boiling the grass in water and use this infusion to scrub and clean insect bite wounds. This infusion is also used in treating acne. In addition, they believe that when the body has been washed with this boiled preparation, they will not be bitten by insects.

In Laos, the Akha have unique uses of fleagrass, including consumption of the fresh leaves as a flavouring, because they like its aroma and piquancy. Fleagrass is also regarded as a ritual plant, and the Akha hang bundles of fleagrass in their granaries as an offering in hope of a bumper harvest.

Akha swidden farmers of China and Laos have similar cultivation experiences. They cultivate fleagrass together with upland rice as an inter-cropping system. Fleagrass seeds are planted simultaneously with dry rice seeds in April (the beginning of the rainy season), although in different holes in the fields. Fleagrass plant growth is slower than that of rice plants, and thus, fleagrass plants are always below a canopy of rice foliage, which inhibits fleagrass growth. Swidden farmers harvest rice from fields in October, at which time the fleagrass is flowering. With the rice harvested, the fleagrass is exposed to considerably more sunlight, and the open field conditions are favourable for pollination. When the fleagrass fruits are sufficiently mature, they are harvested for family use. However, with the continuing disappearance of swidden agriculture in China, there are only a few people who still plant fleagrass. Considering the requirement for shade, fleagrass is now planted together with tea trees. The Akha typically collect dried plants bearing seeds, the bundles of which are hung around their homes. The seeds are separated in the following year and subsequently planted. Generally, each family grows fleagrass annually in a small plot of upland rice.

\section{Cultural meanings and beliefs associated with fleagrass}

The Akha people like the scent of fleagrass and often wear fresh or dried branches on their heads as decoration and

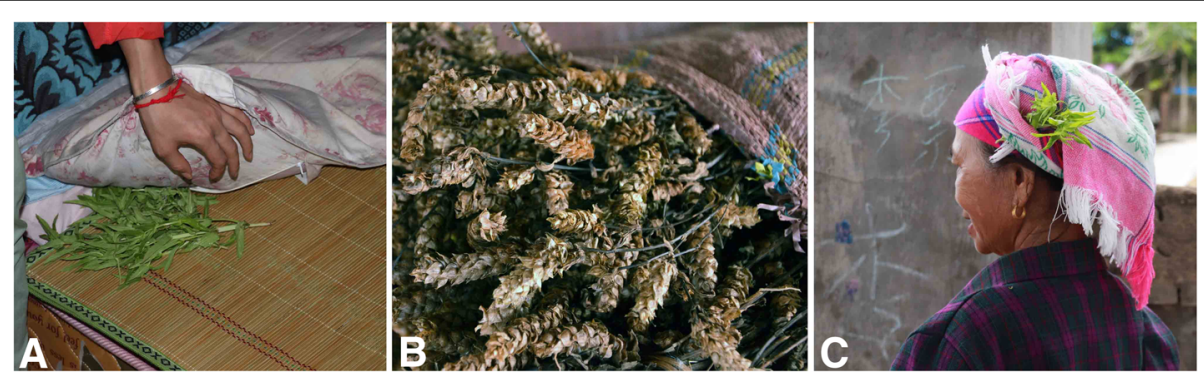

Fig. 4 Fleagrass uses and dried plant. a Put fleagrass on bed. b Dried fleagrass. $\mathbf{c}$ Wear fleagrass on the head (photographed by YG and Changan Guo, made by A. B. Cunningham) 
perfume. Other ethnic groups, including other swidden groups such as the Jino, Yao, Miao, and Lahu, within the same area do not use fleagrass. The Akha people regard it as a tribal symbol, which indicates that they are different from other tribes. Because this kind of grass is only planted and used by the Akha people, when they wear the fleas on the head, they also have a sense of pride and belonging. Akha villagers make use of fleagrass as decorations and perfume in different styles according to age, sexuality, and tribal identity. Elders among the Akha villagers use fleagrass in small bundles to wear in their ear-holes or only in the right ear-hole as a decoration and perfume. Akha women wear a small bundle of fleagrass attached to their colourful woman's cap. However, Akha men and little boys and little girls do not usually make use of fleagrass as a decoration.

Akha young men and women enjoy full social freedom. Each village has a 'public house' that is dedicated to providing space for young people to have parties and dates. Unmarried men and women can go to the public house to sing, dance, play, and talk to each other about love. When the young girl or boy comes to date, he or she will wear the fleagrass on his or her head as a sign. The girls put a bunch of fleagrass on the laces of their hats. The boys also wear a bunch of fleagrass on their ears. The scent of fleagrass makes the public house full of pleasant, fragrant tastes and provides a romantic atmosphere. When a young person falls for someone, they will also give 'fleas grass' as a gift of love.

Traditionally, the Akha have been a migratory people who practice swidden (slash and burn) agriculture. The mountain crops mainly include upland rice, corn, and cotton. The Akha plant fleagrass together with upland rice as an inter-cropping system. When the rice matures, the Akha harvest it and store the rice in the barn. At the same time, they pick up a bunch of fleagrass that is hanging outside the barn. This is a ritual that is used to pray for stored crops without insects and for the crops of the upcoming year to be bumper harvested without pests and disease.

\section{The rise and fall of fleagrass in China}

Previously, there was no record of A. buchneroides in China, until Shen et al. (1991) found that fleagrass was introduced into swidden cultivating systems by Akha people in the Xishuangbanna area and served as a useful plant a long time ago [12]. Because the Akha people do not have tribal scripts, their knowledge of plant uses is passed on verbally, and thus, there is no written record about fleagrass in China in ancient times. When and how the Hani began their domestication of the plant in the area remains uncertain.

In China, someone said the Akha name of fleagrass 'Lao-wo-suo-du' means 'grass that is from Laos'; 'Lao wo' means Laos in Chinese. Two informants reported a legend about the name. A short man brought fleagrass from Laos, and he sent it to the local people, but the local people did not take it because they did not know what it was. Then, the short man spread it everywhere, and there was abundant fleagrass in the field. Thus, they call it 'Lao-wo-suo-do'. This legend may explain how fleagrass came to China from Laos. However, current wild distribution of fleagrass occurs only in Vietnam. It is still unclear how fleagrass spread from Vietnam.

A. buchneroides was first described in 'Bulletin de la Société Botanique de Genève' in 1913 by Bonati, who collected specimens in Vietnam and introduced A. buchneroides as an aromatic plant [15]. However, 'Flore Du Cambodge, Du Laos, Et Du Vietnam,' 'Checklist of Plant Species of Vietnam,' 'Flora Yunnan' and 'Flora of Thailand' do not recognize $A$. buchneroides as an individual species, they all regard it as a synonym of $A$. indianum [26-29]. A. buchneroides and $A$. indianum have the same Vietnamese name 'Bobo' [27]. A. indianum is also a Chinese medicine, and Chinese residents use it to cure colds, headaches, fevers, bellyaches, diarrhoea, cacochylia, and dermatitis [13]. These uses are similar with the uses for $A$. buchneroides. A. buchneroides and A. indianum have many similarities, but they also have some differences. The flowers of $A$. buchneroides and A. indianum densely connate and formatted into terminal or capitate spikes, but the inflorescence of $A$. buchneroides is longer than that of A. indianum.

Therefore, there are two hypotheses about the origin of fleagrass. Maybe it was disseminated from Vietnam through Laos to China. It is also possible that fleagrass was domesticated from $A$. indianum, and the inflorescence became longer in the process of cultivating. Testing these hypotheses requires more in-depth investigations and molecular evidence.

No matter how it begins, the current situation of fleagrass is not optimistic. With the continuing population growth and the introduction of cash crops and new policies, swidden agriculture in China is being replaced and is disappearing. Therefore, the resource of fleagrass is in danger of vanishing, particularly in China. Moreover, with improvements in the living standards of the Akha people, modern goods are increasingly replacing traditional materials. Therefore, the importance of fleagrass in Akha villages is declining, and with this decline, the traditional knowledge of fleagrass is becoming lost. Through field surveys, we accessed a total of 45 interviewees from Xishuangbanna Dai Autonomous Prefecture, Southwest China. There are 31 interviewees who have knowledge of a plant called fleagrass (or 'lao-wo-suo-du' in the Akha dialect) with morphological features as presented to them during the survey. Most of them have not cultivated fleagrass since 1990, when they began the large-scale 
planting of rubber. The significance of fleagrass in Akha traditional culture is therefore likely to die with reduced resources. An overwhelming majority of the young generation of Akha claim that they never see this plant and do not know about it. During the survey, we found only three people who continue to use fleagrass today. They save seeds and plant them in small scale, and they use fleagrass mostly in perfumes, to repel insects and alleviate insect bites, while other medical uses have been replaced by modern medicine.

Although fleagrass has died down from the daily life of the Akha people in China, they still remember the uses of fleagrass, and they yearn for it. When we showed the plant to the Akha people, they were happy and wanted to replant it. In the process of modernization, they accidentally lost fleagrass. However, fleagrass is able to occupy an important position again, as long as they are given the opportunity to replant it.

Compared to China, Akha of Laos still retain swidden agriculture, and the fleagrass resources are preserved. Considering the economic conditions and the convenience of life in Laos, the life of the Akhas is still heavily dependent on the resources of the forest plants, so the traditional knowledge of the fleagrass has been preserved. In Laos, each of the 19 interviewees we accessed know and use fleagrass now, and the mean age is 43 years old, which is younger than that of the respondents of China.

In conclusion, we think the vanishing of swidden agriculture and the development of modern products are the main reasons why fleagrass in China is disappearing. Nevertheless, we found that few Akha people of China continue to use fleagrass in perfume, to repel insects and to alleviate insect bites. Therefore, we think that fleagrass is effective at repelling insects and alleviating insect bites, but it is not widely known.

\section{The scientific basis of folk usages}

Shen et al. [12] and $\mathrm{Xu}$ et al. [15] have examined the chemical constituents of the essential oil of fleagrass, identifying 26 and 34 chemical compounds, respectively. Most of the chemical constituents identified were common to both studies, and in total, 39 different constituents were recorded. However, the contents of the main compounds showed considerable variation, which could be attributable to differences in the materials examined. Shen et al. (1991) collected mature whole plants and dried plants that are harvested from swidden fields by Akha villagers [12], whereas $\mathrm{Xu}$ et al. collected the aerial parts of fleagrass planted in gardens [15].

Fleagrass is an important and useful aromatic plant with a distinct aroma. The main chemical constituents of the essential oil are terpenoids, which have distinct odours and bioactivities. We selected 23 compounds that have biological activities that are related to the ethnobotanical uses of fleagrass, as shown in Table 2. Thymol, carvacrol, 3-carene, $p$-cymene, $\beta$-phellandrene, $\alpha$-phellandrene, cuminic acid, $\beta$-bisabolene, $\alpha$-pinene, and limonene are the main constituents of the essential oil of fleagrass. The bioactivities of these constituents can be divided into six categories: antimicrobial, sterilization, insecticidal, insect repellent, anti-inflammatory, and anti-viral.

As shown in Table 2, the majority of these 23 compounds, including thymol, carvacrol, 3-carene, and $p$-cymene, have been proven to have insecticide or insect-repellent activities, by virtue of their odour or contact toxicity. Traditionally, Akha villagers placed bundles of fleagrass in their rooms or caps and utilized the aroma to repel insects. The Akha villagers of Laos hung fleagrass on the wall of granaries and planted it in the field to protect the grains from grain pests which benefits the crop harvest. Therefore, they used fleagrass to pray for a bumper harvest. However, the Akha live in a humid tropical mountainous region where insect bites cannot be completely avoided. Such bites are often accompanied by swelling, itching, and even secondary infection. Like many other traditional plants used to treat itching skin, the mechanism of fleagrass is used to treat insect bites. Nevertheless, the analgesic activity of carvacrol and the anti-inflammatory activity of several chemicals are helpful in relieving pain and preventing infection.

Some aromatic compounds, such as pinene, can be used as relaxants to reduce fatigue and thus may have a beneficial aromatherapeutic effect. Akha villagers are accordingly fond of using fleagrass as a fragrance. Thymol, one of the main constituents, exhibited high anti-viral activity, which may be useful in relieving headache, stuffy nose, and influenza.

Fleagrass is also used as a food condiment by the Akha of northern Laos. In addition to its odour and taste, we believe that this use may be related to the plant's content of antimicrobial compounds. Temperatures in the regions inhabited by the Akha are generally high, and people like to eat raw materials; thus, there may be plenty of microorganisms in the food. The antibacterial and fungicide activities of fleagrass are helpful in keeping food fresh and safe to consume.

\section{Conclusion}

Fleagrass is a versatile aromatic plant that is traditionally planted in swidden fields by the Akha people. With the vanishing of swidden agriculture and the development of modern products, fleagrass in China is disappearing, and its cultural importance has been reduced. However, its economic and medicinal value is assignable. On the basis of an ethnobotanical survey of fleagrass in northern Laos and in China, we documented the Akha villagers' use of fleagrass as a perfume, insect repellent, condiment, herbal medicine, and ritualistic plant. To the best of our knowledge, we report here for the first time that Akha 
Table 2 Twenty-three compounds and their bioactivities related to ethnobotanical uses of fleagrass

\begin{tabular}{|c|c|c|c|c|}
\hline Compound & $\begin{array}{l}\text { Content \% } \\
\text { (Shen et al. 1991) [12] }\end{array}$ & $\begin{array}{l}\text { Content \% } \\
\text { (Xu et al. 2005) [15] }\end{array}$ & Bioactivity & Reference \\
\hline 3-Hexenol & 0.01 & 0.04 & Insect pest control & {$[30,31]$} \\
\hline a-Pinene & 0.36 & 1.24 & Antibacterial; antifungal; insect repellent & [32-34] \\
\hline Sabinene & 0.01 & - & Antibacterial; insect repellent & {$[35,36]$} \\
\hline$\beta$-Pinene & 0.01 & 0.05 & Antibacterial; antifungal; antidepressant; insecticide & {$[32,33,37,38]$} \\
\hline a-Phellandrene & 11.86 & 0.11 & Antimicrobial; insecticide & {$[39,40]$} \\
\hline 3-Carene & 0.36 & 1.67 & Oviposition deterrent insect repellent; antibacterial & {$[17,19]$} \\
\hline p-Cymene & 4.40 & 6.60 & Oviposition deterrent; antibacterial; insecticide & {$[16,41,42]$} \\
\hline Limonene & 0.39 & 2.49 & $\begin{array}{l}\text { Oviposition deterrent; insecticide; insect } \\
\text { repellent; antimicrobial }\end{array}$ & {$[42-44]$} \\
\hline$\beta$-Phellandrene & 11.86 & - & Insecticide & [45] \\
\hline Terpinolene & 0.01 & 0.33 & Insecticide; insect repellent & [46] \\
\hline Linalool & 0.04 & 0.05 & $\begin{array}{l}\text { Antimicrobial; insecticide; antidepressant; } \\
\text { anticonflict effects }\end{array}$ & {$[38,47-49]$} \\
\hline 4-Terpineol & 0.06 & 0.08 & $\begin{array}{l}\text { Antimicrobial; insecticide; insect repellent; } \\
\text { anti-inflammatory }\end{array}$ & {$[50-53]$} \\
\hline a-Terpineol & 0.08 & 0.13 & Antimicrobial; anti-inflammatory & {$[47,52,54]$} \\
\hline Cuminic acid & 11.17 & - & Fungicide & [55] \\
\hline Carvone & 0.03 & 0.02 & Antimicrobial; insect repellent & {$[34,43]$} \\
\hline Carvacrol & 0.78 & 34.78 & $\begin{array}{l}\text { Antimicrobial; anti-inflammatory; } \\
\text { analgesic; insecticide }\end{array}$ & {$[16,56,57]$} \\
\hline Thymol & 52.48 & 0.70 & $\begin{array}{l}\text { Antibacterial; insecticide; antioxidant; } \\
\text { antimicrobial; anti-viral }\end{array}$ & {$[18,58-61]$} \\
\hline$\beta$-Caryophyllene & 0.08 & 0.17 & Insecticide; anti-inflammatory; antibacterial & {$[37,62]$} \\
\hline$\beta$-Bisabolene & 10.57 & 1.34 & Synergistic bactericidal; insect repellent & {$[17,63]$} \\
\hline Farnesene & 0.69 & - & Insect repellent & [64] \\
\hline Guaiol & 0.57 & - & Insecticide & {$[65]$} \\
\hline Eugenol & - & 0.02 & $\begin{array}{l}\text { Insecticide, insect repellent; antifungal; } \\
\text { anti-inflammatory }\end{array}$ & {$[36,66,67]$} \\
\hline Caryophyllene oxide & - & 0.01 & Anti-platelet aggregation; antifungal; insecticide & {$[46,68,69]$} \\
\hline
\end{tabular}

villagers crush fresh fleagrass and apply it to the skin to treat insect bites, and the Akha in northern Laos eat the fresh leaves of fleagrass as a flavouring. Furthermore, they hang bundles of fleagrass in their granaries as a ritualistic offering in the hope of a bumper harvest. From our literature review, we identified chemical constituents of the essential oil of fleagrass that have good bioactivities related to antimicrobial, sterilization, insecticidal, insect repellent, anti-inflammatory, and anti-viral properties. Overall, we consider that fleagrass is a multi-functional plant with tribal characteristics, particularly with respect to its use as an insect repellent and in the treatment of insect bites.

Although some of the aforementioned folk uses can be assigned tentatively to the bioactivities of certain chemical constituents that are found in fleagrass, further targeted research is warranted in this respect. As a traditional insect repellent, further in-depth research on fleagrass may help us to develop new, effective plant-based repellents. In addition, with continuing economic development and environmental changes, the resources and traditional knowledge of fleagrass are in danger of vanishing. As an important plant resource, we should focus on the protection and exploitation of fleagrass. We therefore highlight the need for further research that focuses particularly on the cultivation of fleagrass, the biological activities of its essential oil or extracts, the mechanisms underlying its various activities, and product development.

\section{Additional file}

Additional file 1: Interview information about Fleagrass. (XLS $69 \mathrm{~kb}$ )

Abbreviations

FC: Frequency of citation; FCU: Frequency of current use 


\section{Acknowledgements}

We are most grateful to all respondents for their hospitality and willingness to share their knowledge of fleagrass with us. We are also most grateful to Mr. Congde Li for his language help and Prof. A. B. Cunningham for his suggestions. We are also very thankful to Prof. Youkai Xu from XTBG, Prof. Zhizhi Du from KIB, Dr Qing Yang from KIB and Ms Chen Wang from KIB for their help in the field.

\section{Funding}

This work was supported by the National Natural Science Foundation of China [31670337] and Plant germplasm resources innovation project of Chinese Academy of Sciences [ZSZC-012].

\section{Availability of data and materials}

The datasets used and/or analysed during the current study are available from the corresponding author on reasonable request.

\section{Authors' contributions}

The study was designed and supervised by YW. YG, RF, and YW carried out the survey and collected the data. YG drafted the manuscript, and SP revised the manuscript. All authors read and approved the final manuscript.

\section{Ethics approval and consent to participate}

Prior informed consent to record and publish their traditional knowledge was obtained verbally from informants before they were interviewed.

\section{Consent for publication}

Not applicable.

\section{Competing interests}

The authors declare that they have no competing interest.

\section{Publisher's Note}

Springer Nature remains neutral with regard to jurisdictional claims in published maps and institutional affiliations.

\section{Author details}

${ }^{1}$ Department of Economic Plants and Biotechnology, Yunnan Key Laboratory for Wild Plant Resources, Kunming Institute of Botany, Chinese Academy of Sciences, 132\# Lanhei Road, Kunming 650201, China. ${ }^{2}$ University of Chinese Academy of Sciences, Beijing 100049, China.

\section{Received: 4 April 2018 Accepted: 21 November 2018}

\section{Published online: 21 December 2018}

\section{References}

1. WHO. Global vector control response 2017-2030. 2017. http://www.who.int/ vector-control/publications/global-control-response/en/. Accessed 15 June 2018.

2. Sukumar K, Perich MJ, Boobar LR. Botanical derivatives in mosquito control: a review. J Am Mosq Control Assoc. 1991;7(2):210-37. https://doi.org/10. 1016/0020-7322(91)90007-V.

3. Moore S, Debboun M. The history of insect repellents. In: Govere JM, Durrheim DN, editors. Insect repellents: principles, methods and uses. Boca Raton : CRC Press; 2006;3-29.

4. Herodotus. The histories. London: Penguin; 1996

5. Yang $\mathrm{CL}$, Jiang $\mathrm{SH}, \mathrm{Xu} \mathrm{HH}$. Research progresses in plant-originated repellents. Plant Prot. 2006;06:4-9. https://doi.org/10.3969/j.issn.0529-1542. 2006.06.002.

6. González JA, Garcíabarriuso M, Gordaliza M, Amich F. Traditional plant-based remedies to control insect vectors of disease in the Arribes del Duero (western Spain): an ethnobotanical study. J Ethnopharmacol. 2011;138(2): 595-601. https://doi.org/10.1016/j.jep.2011.10.003.

7. de Boer H, Vongsombath C, Pålsson K, Björk L, Jaenson TG, et al. Botanical repellents and pesticides traditionally used against hematophagous invertebrates in Lao People's Democratic Republic: a comparative study of plants used in 66 villages. J Med Entomol. 2010;47(3):400. https://doi.org/10. 1603/ME09273.

8. Youmsi R, Fokou P, Menkem EZ, Bakarngavia I, Keumoe $R$, et al. Ethnobotanical survey of medicinal plants used as insects repellents in six malaria endemic localities of Cameroon. J Ethnobiol Ethnomed. 2017;13(1): 33. https://doi.org/10.1186/s13002-017-0155-x.

9. Karunamoorthi K, Hailu T. Insect repellent plants traditional usage practices in the Ethiopian malaria epidemic-prone setting: an ethnobotanical survey. J Ethnobiol and Ethnomed. 2014;10(1):22. https://doi.org/10.1186/1746-4269-10-22.

10. Sãuukand R, Kalle R, Svanberg I. Uninvited guests: traditional insect repellents in Estonia used against the clothes moth Tineola bisselliella, human flea Pulex irritons and bedbug Cimex lectularius. J Insect Sci. 2010; 10(1):150. https://doi.org/10.1673/031.010.14110.

11. Hwang YS, Wu KH, Kumamoto J, Axelrod H, Mulla MS. Isolation and identification of mosquito repellents in Artemisia vulgaris. J Chem Ecol. 1985 11:1297-306. https://doi.org/10.1007/BF01024117.

12. Shen PQ, Sun HD, Pei SJ. Ethnobotany of fleagrass (Adenosma Buchneroides Bonati), a traditional cultivated plant of the Hani people, Xishuangbanna, Yunnan, China. In: The Museum, 1990, vol. 1. Belém: Ethnobiology: implications and applications: proceedings of the First International Congress of Ethnobiology; 1988.

13. Yunnan Medicine Company. Directory of Yunnan traditional Chinese medicine. Beijing: Science Press; 1993.

14. Li H, Li R, Wei M, Yi P, Ke Z, Nan Y. Effect of 25 plant essential oils against Callosobruchus maculatus. In: Proceeding of the 7th International Working Conference on Stored-product Protection, vol. 1; 1998.

15. $X u$ Y, Cheng BQ, Yu Z, Ding JK. A preliminary study on the new perfume plant Adenosma buchneroides Bonati. In: The Seventh China Academic Symposium on Fragrance; Hangzhou, Zhejiang, China; 2008.

16. Kordali S, Cakir A, Ozer H, Cakmakci R, Kesdek M, Mete E. Antifungal, phytotoxic and insecticidal properties of essential oil isolated from Turkish Origanum acutidens and its three components, carvacrol, thymol and pcymene. Bioresour Technol. 2008;99(18):8788-95. https://doi.org/10.1016/j. biortech.2008.04.048.

17. Nascimento AMA, Brandão MGL, Oliveira GB, Fortes ICP, Chartone-Souza E. Synergistic bactericidal activity of Eremanthus erythropappus oil or $\beta$ bisabolene with ampicillin against Staphylococcus aureus. Antonie Van Leeuwenhoek. 2007:92(1):95-100. https://doi.org/10.1007/s10482-006-9139-x.

18. Fitsiou E, Anestopoulos I, Chlichlia K, Galanis A, Kourkoutas I, Panayiotidis MI, Pappa A. Antioxidant and antiproliferative properties of the essential oils of Satureja thymbra and Satureja parnassica and their major constituents. Anticancer Res. 2016;36(11):5757-63. https://doi.org/ 10.21873/anticanres.11159.

19. Cheng SS, Chua MT, Chang EH, Huang CG, Chen WJ, Chang ST. Variations in insecticidal activity and chemical compositions of leaf essential oils from Cryptomeria japonica at different ages. Bioresour Technol. 2009;100(1): 465-70. https://doi.org/10.1016/j.biortech.2007.11.060.

20. Bonati GH. Bulletin de la Société Botanique de Genève. 1913;2(5):314.

21. Wang GQ. National compilation of Chinese herbal medicine (volume 2). 3rd ed. Beijing: People's Medical Publishing House; 2014.

22. Office of the Government of Xishuangbanna Dai Autonomous Prefecture. The profile of Xishuangbanna Dai Autonomous Prefecture. 2018. http://www.xsbn.gov.cn/88.news.detail.dhtml?news_id=34206. Accessed 25 July 2018.

23. Cao M, Zou X, Warren M, Zhu H. Tropical forests of Xishuangbanna. China Biotropica. 2006;38(3):306-9. https://doi.org/10.1111/j.1744-7429.2006.00146.x.

24. Xishuangbanna Dai Autonomous Prefecture Annual Editorial Board. Xishuangbanna Dai autonomous prefecture annual. Beijing: Xinhua Publishing House; 2001.

25. Wikipedia. Phongsaly province. In: . https://en.wikipedia.org/wiki/Phongsaly_ Province. Accessed 25 Dec. 2017

26. Yamazaki T. Flore du Cambodge du Laos et du Vietnam, Fascicule 21. Paris: Laboratoire de Phanerogamie; 1985.

27. Le Trong C. Checklist of plant species of Vietnam (III). Nha Xuat Ban Nong Nghiep: Hanoi; 2003.

28. Smitinand T. Flora of Thailand volume 5(2). Bangkok The Forest Herbarium: Royal Forest Department; 1990.

29. Kunming Institute of Botany, Chinese Academic Sciences. Flora Yunnanica, vol. 16. Beijing: Science Press; 1979.

30. Grant GG, Ryall KL, Lyons DB, Abou-Zaid MM. Differential response of male and female emerald ash borers (Col., Buprestidae) to (Z)-3-hexenol and manuka oil. J Appl Entomol. 2010;134(1):26-33. https://doi.org/10.1111/j. 1439-0418.2009.01441.x.

31. Wei J, Kang L. Roles of (Z)-3-hexenol in plant-insect interactions. Plant Signal Behav. 2011;6(3):369-71. https://doi.org/10.4161/psb.6.3.14452. 
32. Hammer KA, Carson CF, Riley TV. Antifungal activity of the components of Melaleuca alternifolia (tea tree) oil. J Appl Microbiol. 2003;95(4):853-60. https://doi.org/10.1046/j.1365-2672.2003.02059.x.

33. Silva ACR, Lopes PM, Azevedo MMB, Costa DCM, Alviano CS, Alviano DS. Biological activities of a-pinene and $\beta$-pinene enantiomers. Molecules. 2012; 17(12):6305-16. https://doi.org/10.3390/molecules17066305.

34. Liang Y, Li JL, Xu S, Zhao NN, Zhou LG, Cheng J, Liu ZL. Evaluation of repellency of some Chinese medicinal herbs essential oils against Liposcelis bostrychophila (Psocoptera: Liposcelidae) and Tribolium castaneum (Coleoptera: Tenebrionidae). J Econ Entomol. 2013;106(1):513-9. https://doi. org/10.1603/EC12247.

35. Matias EFF, Alves EF, Silva MKN, Carvalho VRA, Figueredo FG, Ferreira JVA, Coutinho HDM, Silva JMFL, Ribeiro-Filho J, Costa JGM. Seasonal variation, chemical composition and biological activity of the essential oil of Cordia verbenacea DC (Boraginaceae) and the sabinene. Ind Crop Prod. 2016;87:4553. https://doi.org/10.1016/j.indcrop.2016.04.028.

36. Wang CM, Zhang J, Chen H, Fan YJ, Shi ZQ. Antifungal activity of eugenol against Botrytis cinerea. Trop Plant Pathol. 2010;35(3):137-43. https://doi.org/ 10.1590/S1982-56762010000300001.

37. Zhang WJ, You CX, Yang K, Chen R, Wang Y, Wu Y, Geng ZF, Chen HP, Jiang HY, Su Y, et al. Bioactivity of essential oil of Artemisia argyi Lévl. et Van. and its main compounds against Lasioderma serricorne. J Oleo Sci. 2014; 63(8):829-37. https://doi.org/10.5650/jos.ess14057.

38. Guzman-Gutierrez SL, Gomez-Cansino R, Garcia-Zebadua JC, Jimenez-Perez NC, Reyes-Chilpa R. Antidepressant activity of Litsea glaucescens essential oil: identification of beta-pinene and linalool as active principles. J Ethnopharmacol. 2012;143(2):673-9. https://doi.org/10.1016/j.jep.2012.07.026.

39. Park IK, Lee SG, Choi DH, Park JD, Ahn YJ. Insecticidal activities of constituents identified in the essential oil from leaves of Chamaecyparis obtusa against Callosobruchus chinensis (L.) and Sitophilus oryzae (L.). J Stored Prod Res. 2003;39(4):375-84. https://doi.org/10.1016/S0022474X(02)00030-9.

40. Iscan G, Kirimer N, Demirci F, Demirci B, Noma Y, Baser KHC. Biotransformation of (-)-(R)-a-phellandrene: antimicrobial activity of its major metabolite. Chem Biodivers. 2012;9(8):1525-32. https://doi.org/10.1002/cbdv.201100283.

41. Bagamboula CF, Uyttendaele M, Debevere J. Inhibitory effect of thyme and basil essential oils, carvacrol, thymol, estragol, linalool and p-cymene towards Shigella sonnei and S. flexneri. Food Microbiol. 2004;21(1):33-42. https://doi.org/10.1016/S0740-0020(03)00046-7.

42. Ntiamoah YA, Borden JH, Pierce HD. Identity and bioactivity of oviposition deterrents in pine oil for the onion maggot, Delia antiqua. Entomol Exp Appl. 1996;79(2):219-26. https://doi.org/10.1111/j.1570-7458.1996.tb00829.x.

43. Aggarwal KK, Khanuja SPS, Ahmad A, Santha Kumar TR, Gupta VK, Kumar S. Antimicrobial activity profiles of the two enantiomers of limonene and carvone isolated from the oils of Mentha spicata and Anethum sowa. Flavour Frag J. 2002;17(1):59-63. https://doi.org/10.1002/ffj.1040.

44. Ibrahim MA, Kainulainen P, Aflatuni A, Tiilikkala K, Holopainen JK. Insecticidal, repellent, antimicrobial activity and phytotoxicity of essential oils: with special reference to limonene and its suitability for control of insect pests. Agr Food Sci Finland. 2001;10(3):243-59.

45. Coats JR, Karr LL, Drewes CD. Toxicity and neurotoxic effects of monoterpenoids: in insects and earthworms. ACS Publications. 1991;449: 305-16. https://doi.org/10.1021/bk-1991-0449.ch020.

46. You C-X, Jiang H-Y, Zhang W-J, Guo S-S, Yang K, Lei N, Ma P, Geng ZF, Du SS. Contact toxicity and repellency of the main components from the essential oil of Clausena anisumolens against two stored product insects. J Insect Sci. 2015;15. https://doi.org/10.1093/jisesa/iev071.

47. Park SN, Lim YK, Freire MO, Cho E, Jin D, Kook JK. Antimicrobial effect of linalool and alpha-terpineol against periodontopathic and cariogenic bacteria. Anaerobe. 2012;18(3):369-72. https://doi.org/10.1016/j.anaerobe.2012.04.001.

48. Beier RC, Byrd JA, Kubena LF, Hume ME, McReynolds JL, Anderson RC, Nisbet DJ. Evaluation of linalool, a natural antimicrobial and insecticidal essential oil from basil: effects on poultry. Poultry Sci. 2014;93(2):267-72. https://doi.org/10.3382/ps.2013-03254.

49. Umezu T, Nagano K, Ito H, Kosakai K, Sakaniwa M, Morita M. Anticonflict effects of lavender oil and identification of its active constituents. Pharmacol Biochem Behav. 2006;85(4):713-21. https://doi.org/10.1016/j.pbb.2006.10.026.

50. Brand C, Grimbaldeston MA, Gamble JR, Drew J, Finlay-Jones JJ, Hart PH. Tea tree oil reduces the swelling associated with the efferent phase of a contact hypersensitivity response. Inflamm Res. 2002;51(5):236-44. https:// doi.org/10.1007/PL00000299.
51. Hart PH, Brand C, Carson CF, Riley TV, Prager RH, Finlay-Jones JJ. Terpinen-4$\mathrm{ol}$, the main component of the essential oil of Melaleuca alternifolia (tea tree oil), suppresses inflammatory mediator production by activated human monocytes. Inflamm Res. 2000;49(11):619-26. https://doi.org/10.1007/ s000110050639.

52. Raman A, Weir U, Bloomfield SF. Antimicrobial effects of tea-tree oil and its major components on Staphylococcus aureus, Staph. epidermidis and Propionibacterium acnes. Lett Appl Microbiol. 1995;21(4):242-5. https://doi. org/10.1111/j.1472-765X.1995.tb01051.X.

53. Wang Y, You CX, Yang K, Wu Y, Chen R, Zhang WJ, Liu ZL, Du SS, Deng ZW, Geng ZF, et al. Bioactivity of essential oil of Zingiber purpureum rhizomes and its main compounds against two stored product insects. J Econ Entomol. 2015;108(3):925-32. https://doi.org/10.1093/jee/tov030.

54. Held S, Schieberle P, Somoza V. Characterization of alpha-terpineol as an anti-inflammatory component of orange juice by in vitro studies using oral buccal cells. J Agr Food Chem. 2007:55(20):8040-6. https://doi.org/10.1021/ jf071691m.

55. Wang $Y$, Sun $Y$, Zhang $Y$, Zhang $X$, Feng J. Antifungal activity and biochemical response of cuminic acid against Phytophthora capsici Leonian. Molecules. 2016;21(6). https://doi.org/10.3390/molecules21060756.

56. Baser KHC. Biological and pharmacological activities of carvacrol and carvacrol bearing essential oils. Curr Pharm Design. 2008;14(29):3106-19. https://doi.org/10.2174/138161208786404227.

57. Silva JC, Almeida J, Quintans JSS, Gopalsamy RG, Shanmugam S, Serafini MR, Oliveira MRC, Silva BAF, Martins A, Castro FF, et al. Enhancement of orofacial antinociceptive effect of carvacrol, a monoterpene present in oregano and thyme oils, by beta-cyclodextrin inclusion complex in mice. Biomed Pharmacother. 2016:84:454-61. https://doi.org/10.1016/j.biopha.2016.09.065.

58. Cosentino S, Tuberoso CIG, Pisano B, Satta M, Mascia V, Arzedi E, Palmas F. In-vitro antimicrobial activity and chemical composition of Sardinian Thymus essential oils. Lett Appl Microbiol. 1999;29(2):130-5. https://doi.org/10.1046/j. 1472-765X.1999.00605.X.

59. Johnson HA, Rogers LL, Alkire ML, McCloudand TG, McLaughlin JL. Bioactive monoterpenes from Monarda fistulosa (Lamiaceae). Nat Prodt Lett. 1998; 11(4):241-50. https://doi.org/10.1080/10575639808044955.

60. Ait-Ouazzou A, Cherrat L, Espina L, Lorán S, Rota C, Pagán R. The antimicrobial activity of hydrophobic essential oil constituents acting alone or in combined processes of food preservation. Inno Food Sci Emerg. 2011; 12(3):320-9. https://doi.org/10.1016/j.jfset.2011.04.004.

61. Lai WL, Chuang HS, Lee MH, Wei CL, Lin CF, Tsai YC. Inhibition of herpes simplex virus type 1 by thymol-related monoterpenoids. Planta Med. 2012; 78(15):1636-8. https://doi.org/10.1055/s-0032-1315208.

62. Naz T, Packer J, Yin P, Brophy JJ, Wohlmuth H, Renshaw DE, Smith J, Elders YC, Vemulpad SR, Jamie JF. Bioactivity and chemical characterisation of Lophostemon suaveolens--an endemic Australian Aboriginal traditional medicinal plant. Nat Prod Res. 2016;30(6):693-6. https://doi.org/10.1080/ 14786419.2015.1038260.

63. Shimidzu N, Katsuoka M, Mizobuchi S, Ina K, Miki W. Isolation of (-)- $\beta$ bisabolene as a repellent substance against blue mussel from an octocoral Sinularia sp. Nippon Suisan Gakk. 1993;59(11).

64. Lambers DHR, Schepers A. The effect of trans- \-farnesene, used as a repellant against landing aphid alatae in seed potato growing. Potato Res. 1978;21(1):23-6. https://doi.org/10.1007/BF02362255.

65. Liu T, Wang CJ, Xie HQ, Mu Q. Guaiol - a naturally occurring insecticidal sesquiterpene. Nat Prod Commun. 2013;8(10):1353-4.

66. Obeng-Ofori D, Reichmuth C. Bioactivity of eugenol, a major component of essential oil of Ocimum suave (wild.) against four species of stored-product Coleoptera. Int J Pest Manage. 1997;43(1):89-94. https://doi.org/10.1080/ 096708797229040.

67. Esmaeili F, Rajabnejhad S, Partoazar AR, Mehr SE, Faridi-Majidi R, Sahebgharani M, Syedmoradi L, Rajabnejhad MR, Amani A. Anti-inflammatory effects of eugenol nanoemulsion as a topical delivery system. Pharm Dev Technol. 2016; 21(7):887-93. https://doi.org/10.3109/10837450.2015.1078353.

68. Lin WY, Kuo YH, Chang YL, Teng CM, Wang EC, Ishikawa T, Chen IS. Anti-platelet aggregation and chemical constituents from the rhizome of Gynura japonica. Planta Med. 2003;69(08):757-64. https://doi.org/10.1055/s-2003-42796.

69. Yang D, Michel L, Chaumont JP, Millet-Clerc J. Use of caryophyllene oxide as an antifungal agent in an in vitro experimental model of onychomycosis. Mycopathologia. 2000;148(2):79-82. https://doi.org/10.1023/A: 1007178924408 